\title{
The Book of Jeremiah: Realisation of threats of the Torah - and also of promises?
}

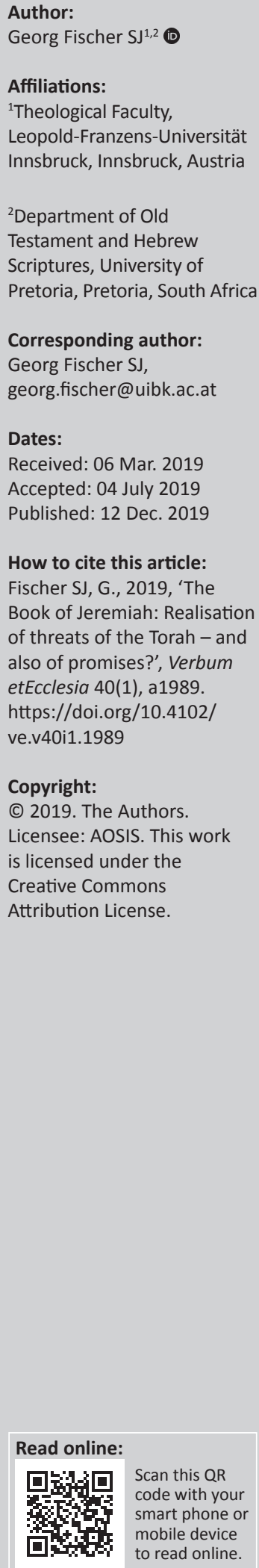

The relationship between the Torah and the Prophets has been a matter of dispute. This article discusses the links of the Book of Jeremiah especially with the warnings in Leviticus 26 and the curses in Deuteronomy 28, but then goes on to show that it also picks up promises from the Torah and thus indicates a way to salvation. In doing so, it comes close to the Book of Isaiah. The intertextual comparison between these two prophetic books reveals that the entire Book of Isaiah may be the source for similar announcements in the Book of Jeremiah, yet also for taking a more nuanced stance.

Intra-disciplinary and/or interdisciplinary implications: The literary relationship between the Torah and Prophets as well as between the Books of Isaiah and Jeremiah is seen anew from an Old Testament perspective with its dogmatic implication for a portrayal of God.

Keywords: Relationship Torah - Jeremiah; Leviticus 26; Deuteronomy 28; Fulfilment of Torah Promises; Relationship Book of Isaiah - Book of Jeremiah.

\section{Introduction}

The Pro Pent congress 2014 on 'Torah and Prophets: Isaiah and Jeremiah' invited participants to reflect on two fascinating relationships, namely, firstly, on the connection between two large parts of the Tanak, and secondly, on the link between two major prophetic books. I will deal with both topics, taking as an example the Book of Jeremiah (1), its profile in the realisation of threats (2) and then, more broadly and more specifically, the aspect of the fulfilment of promises contained therein (3); after that, I will address the question of the relationship between the Books of Isaiah and Jeremiah (4).

\section{Who comes first?}

There has been a long debate about the mutual relationship between the Torah and the (latter) Prophets. Books like Amos, Hosea, Micah and Isaiah, for example, refer in their opening verses to the 8 th century BC. If some texts therein may also be ascribed to this time, this would mean that they may predate the 'law', ${ }^{1}$ the Torah or at least parts of it. ${ }^{2}$

On the contrary, most scholars assume that the final form of the prophetic books was composed much later than the initial references would suggest. They originated, for the most part, in postexilic times, probably towards the end of the Persian period and, for some of the later books of the Twelve Minor Prophets, even later than that, in the era of Hellenism. Consequently, the Torah can be taken as prior to them.

\section{What about the book of Jeremiah?}

A similar discussion is going on with regard to the relationship between the Torah and the Book of Jeremiah. ${ }^{3}$ Colleagues taking large parts of Jeremiah as being original, to be attributed to the Prophet himself around $600 \mathrm{BC}$, can propose his influence on, for example, late passages of Deuteronomy. ${ }^{4}$ William L. Holladay and Jack R. Lundbom are representatives of such a position. ${ }^{5}$

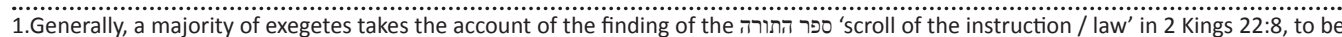
dated to $622 \mathrm{BC}$, as an indication of a preliminary form of what later may have become the Book of Deuteronomy.

2.As a consequence of such a position, the similarity of Hosea 4:2 with the commandments of the Decalogue, for example, is interpreted as an earlier form of the 'Ten Words', still prior to its two versions in Exodus 20 and Deuteronomy 5.

3.Further on it will be abbreviated by 'Jer', whereas 'Jeremiah' refers to the prophet.

4.An example for such a stance is Matthias Köckert (2000:93). He interprets the law on prophets in Deuteronomy 18 as dependent on the call of Jeremiah in Jeremiah 1, taking the opening chapter of Jeremiah as its source.

5.See their commentaries, especially the introduction to Holladay's second volume (1989), and the appendix XI, 'Assigned dates to texts in the Book of Jeremiah' in Lundbom (2004b:582-585); with the exception of Jeremiah 51:12c, 46 and 52:31-34 Lundbom attributes 
The contrasting position sees Jeremiah as a book stemming from a much later time, either in various phases of its supposed 'redaction', or as a whole. This viewpoint reverses the direction of dependence, at least partially, and, as a consequence, the entire Torah may be considered as having been a source for Jer.

\section{A new understanding of Jeremiah}

The commentary of Carroll (1986) has been groundbreaking for the latter approach. Following his lead and insights, I, too, arrived at the conclusion that probably only some of the passages in Jeremiah come from the prophet himself, whereas many parts show later influences and backgrounds.

My research led me to see Jeremiah as a whole as a composition, which was constructed not earlier than the fourth century BC (Fischer 2005a:74). The main reason for this setting is Jeremiah's dependence on many previous scrolls, among them the entire Torah, all the books of the so-called Deuteronomistic History, more than half of the Twelve (Minor Prophets), and even on Isaiah and Ezekiel. ${ }^{6}$

The links of Jeremiah with these scrolls show a new form of intertextuality. Jeremiah, throughout the entire book, makes use of its sources in very special ways:

a. It concentrates on important chapters and events, for example on Genesis 1, the creation narrative; Exodus 20, the Decalogue; Deuteronomy 18, the law on prophets and the announcement of a future prophet like Moses; 2 Samuel 7, the promise of a lasting dynasty for David; 1 Kings 8, Solomon's prayer at the dedication of the temple; 2 Kings 17, the report of the fall of Samariah, etc. ${ }^{7}$

b. Jeremiah chooses very peculiar, rare expressions. Sometimes this establishes a connection which can be called an 'exclusive link', as the respective phrase does not show up elsewhere in the Hebrew Bible. Two examples from the texts mentioned above, out of numerous others all over Jeremiah, are the phrase נתן דברי בפי to give my words into the mouth', with God as subject, only to be found in Deuteronomy 18:18 and in Jeremiah 1:9, and the wordplay וילכו אחרי ההבל ויהבלו 'and they went after the nothing and became nothing', connecting 2 Kings 17:15 and Jeremiah 2:5 in a unique manner.

c. Jeremiah often combines these expressions, thus frequently giving the impression of an 'anthology'. So Jeremiah 2:5 not only quotes 2 Kings 17, but introduces it with a question which alludes by the use of 'iniquity/falseness' for God to Deuteronomy 32:4, the Song of Moses. ${ }^{8}$ Jeremiah's prayer in

(footnote 5 continues...)

everything in Jeremiah to the prophet's lifetime, mostly between the reign of Josiah and $582 \mathrm{BC}$, or shortly afterwards, with the Judahite exiles in Egypt (passage of Jr 43-44)

6.See recently Fischer (2015:95-119).

7.Some of the respective alluding passages in Jeremiah are (in the order of the texts mentioned above): Jeremiah 4:23-25; 7:9; $1: 7,9 ; 31: 9 ; 32: 19 ; 2: 5$ with $11: 9$ among many others. For several aspects of Jeremiah's intertextual character, see the articles collected in part C) in Fischer (2015).

8.The only other occurrence of this term in reference to God is Job 34:10; however this passage is most probably later than Deuteronomy 32 and Jeremiah 2 . For
Jeremiah 32:17-21 has very close, sometimes even exclusive connections to King Hezekiah's prayer in 2 Kings 19:15-16, to God's rhetorical question in Genesis 18:14, to the Decalogues (esp. עשה הסד לאלפים), to Moses' praise of God in Deuteronomy 10:17, and to the 'Creed' in Deuteronomy 26:8. The style of Jeremiah, especially in the poetry, thus resembles a mosaic.

These literary observations can be observed everywhere in Jeremiah and point to a highly developed form of scriptural prophecy. They also allow us to deduce something about the author of Jeremiah. ${ }^{9}$ He must have had access to, and an intimate personal knowledge of nearly half of what later became the Hebrew Bible. This suggests that he, most probably, stayed in Jerusalem, as the most likely place where all these scrolls would have been kept. The manner of dealing with them shows a person with an extremely high literary and theological sensitivity, a very broad horizon, enormous intellectual capacity and deep religious experiences, who had the courage to go even counter to some of the prescriptions of the Torah..$^{10}$

The remarks above are a basis for the following exposition in three parts. I will show how Jeremiah brings the realisation of 'threats' of the Torah, present some themes where Jeremiah can be seen as fulfilment of promises of the Torah and finally address the issue of the relationship between the Book of Isaiah and Jeremiah. ${ }^{11}$

\section{Threats of the Torah realised in Jeremiah}

To get a background for the investigation of the realisation of promises of the Torah in Jeremiah, I will first address the opposite theme, namely, the fulfilment of the aforesaid catastrophe. It occurs much more frequently, as has often been observed, ${ }^{12}$ is sometimes reported in exact correspondences and marks Jeremiah as a book which confirms that the warnings of God and of Moses were to the point.

The most condensed announcements of possible future disasters in the Torah are to be found in Leviticus 26 and Deuteronomy 28 . Both chapters stand near the end of their respective books, take a brief look into what will happen to God's people according to whether or not they listen to him and develop at

\footnotetext{
further connections of Jeremiah with Deuteronomy 32, see Lundbom (1999:110114). Applying the term עול to God is extremely delicate, as it touches the very essence of biblical theology, namely whether God is correct, or false. Although Deuteronomy 32 negates any falseness in Yahweh, God himself, in Jeremiah 2, dares to discuss this issue of such immense importance.

9.Generally, the majority of scholars assume several individuals were involved in the process of writing Jeremiah, and they often suppose various redactions. Yet, the process of writing Jeremiah, and they often suppose various redactions. Yet, the
distribution of the aforementioned specific features is pervasive throughout distribution of the aforementioned specific features is pervasive throughout
Jeremiah and is a reason, together with other traits common to the entire book, to Jeremiah and is a reason, together with other traits common to the entire book, to
opt for the possibility of a single author, too. This does not exclude the use of earlier materials or documents that he incorporated into his book; the clearest example for this procedure is the final chapter Jeremiah 52 , borrowed from the end of 2 Kings, and adapted as well as extended.

10.Jeremiah 3:1-12 runs counter to the law of a released wife in Deuteronomy 24:1-4 Jeremiah $30: 18,21$ abrogates the law of an apostate city in Deuteronomy 13, and 'teaching', highlighted by Braulik (1997), whereas in Jeremiah 31:34 God and 'teaching', highlighted by Braulik (1997), whereas in Jeremiah $31: 34$ God announces that there is no need to teach to know him anymore because all will
have a personal relationship with him.

11.The connection of Isaiah with Jeremiah was a main focus of the ProPent conference 2014; it also serves as a model for Jeremiah's intertextuality.

12.For example, Holladay (1989:79-80).
} 
length the negative side. In these respects, these two chapters of the Torah stand out.

\section{God's warnings in Leviticus 26}

In Leviticus 26, God promises his support in the case of Israel's obedience to his commandments (v3-13); however, if they would not obey, a series of disasters of increasing severity will befall them. This section is much longer (v4-38) and intensifies in five steps the consequences of not listening to God.

A fourfold repeated expression catches what is going on 'behind the scenes' and serves as a Leitmotiv for the chapter, combining both parts. The Hebrew phrase געלה נפש [the soul abhors] is used twice each for the people and for God:

a. Leviticus 26:11 contains a divine promise that this will not happen: '... and I will set up my dwelling among you, and my soul will not abhor you'. This future behavior of God comes close to the end of the positive section; it is only surpassed by God's 'promenading/walking around among them ${ }^{\prime 13}$ and by the Bundesformel in v12 and thus may be regarded as very important.

This announcement, however, is conditionally revoked in sequence by the continued resistance of the people.

b. Their opposition starts in v14-15 with four subordinate phrases with ואם 'but when', the last one of them being '... but if your soul ${ }^{14}$ will abhor my statutes ...'. The position of this expression at the end of the four conditional sentences brings out this misbehavior as the most serious offence against God.

c. It takes a long time, in fact until the very last, fifth step, ${ }^{15}$ that God responds in a kind of retaliation, here announcing in v30 'my soul will abhor you'. This emotional reaction comes quite near the beginning ${ }^{16}$ and stands out in the midst of a long series of destructive activities leading to the desolation of the land and to the exile of its population.

d. Towards the end of the chapter, in v43, God establishes explicitly a connection with Israel's behavior, giving as a reason for his rejection ' ... because their soul has abhorred my stipulations'.

The sequence, the distribution of agents and the linking of these four passages in Leviticus 26 single them out as a key to the understanding of this chapter. The only other occurrence of this phrase in the Hebrew Bible is Jeremiah $14: 19,{ }^{17}$ which is thus exclusively linked to Leviticus 26. The people ask God: 'Have you completely rejected/despised ${ }^{18}$ Judah, does your soul abhor Zion?'

13.This is the only occurrence of the expression בל ברוך hitpael for God; the two other passages in Ezekiel 19:6 and 28:14 refer to a young lion (to be understood for one of the last Judean Kings) and to Tyre.

14.Sic literally; intended is 'you' (in the plural).

15.The progression in Leviticus 26 is indicated by the repeated ואם in v18, 21, 23 and 27.

16.The consequences start in v28 with God's wrath and pass on to eating one's own children in v29; v30 returns to divine activities, first directed against other gods and culminating in his abhorrence of Israel.

17.Observed by Boda (2001:196).

18.The Hebrew phrase uses מאס twice, once in the absolute infinitive, here rendered as 'completely'. The parallelism of 'the soul abhors' and מאס is also present in Leviticus 26:15.
Jeremiah 14:19-22 is a 'false' prayer, ${ }^{19}$ in the sense that the people's attitude is ambiguous. On the one hand, they acknowledge their guilt (e.g. v20) and praise God's uniqueness (v22); on the other hand, their question 'Why have you beaten us, so that there is no healing for us?' in v19 is rather strange and misplaced, after God's lengthy listings of their faults in all the chapters before, and any sign of contrition or request for pardon is missing.

The exclusive link between Leviticus 26 and Jeremiah 14 by this very special, emphasised phrase 'the soul abhors' establishes a strong connection between Jeremiah and the divine threats in Leviticus, and may be an indication that Jeremiah 14 is deliberately evoking Leviticus 26. What God had announced there as a warning, as his reaction towards continued disobedience, seems to become realised now, and the people express it thus by their question.

\section{Moses' curses in Deuteronomy 28}

Deuteronomy 28 is pronounced by Moses and contains 'blessings' (v2) and 'curses' (v15), the respective sections being v1-14 and 15-68. Once again, and even more than in Leviticus 26, the section mentioning the dire consequences of disobedience is larger by far, and it forms the conclusion differing from Leviticus 26, where v39-45 allow us to surmise a positive outcome.

As in the case of Leviticus 26, Jeremiah takes up more the punitive part of Deuteronomy 28, and much more intensively. ${ }^{20}$ In fact, there is no other book of the Bible that uses Deuteronomy 28 more than Jeremiah does. Deuteronomy is the scroll upon which Jeremiah relies the most, and there is no chapter of Deuteronomy that serves more as a source for Jeremiah than 28. All these aspects underline the importance of Deuteronomy's curses for the understanding of Jeremiah

Exclusive links connecting Jeremiah to Deuteronomy 28 are as follows:

Deuteronomy 28:26 / / Jeremiah 7:33 the corpse as a feed for animals Deuteronomy 28:48 // Jeremiah 28:14 the iron yoke

Deuteronomy 28:49 // Jeremiah 5:15 a nation from afar ... whose tongue

Deuteronomy 28:63 / / Jeremiah 32:41 God rejoicing in doing well ${ }^{21}$

Furthermore, there are around 20 other close connections between Deuteronomy 28 and Jeremiah. ${ }^{22}$ These observations point to a literary relationship and a deliberate use of these curses. In the view of Jeremiah, they form the most persuasive basis for understanding Jerusalem's destruction in 587 BC. What Moses had announced has become reality in the Babylonian siege and conquest of Jerusalem. However, as the case of Jeremiah 32:41 as a reversal of Deuteronomy 28:63 shows, God may go beyond 19.See Fischer (2011:379), and idem (2005a:489).

20.For the major connections of Deuteronomy 28 with Jeremiah, see Fischer (2012a).

21. However, Jeremiah 32:41 reverses this curse: God's joy in doing well to his people refers to the past in Deuteronomy 28:63, whereas for the future he will rejoice in harming them. In Jeremiah 32, this curse is dissolved, as God again finds joy in doing good to them in the future. Cf. Fischer (2011: 231-32).

22.Fischer (2012: 45). 
the logic of 'disobedience - destruction' and may grant his grace anew to his completely undeserving people.

The many links between Jeremiah and Deuteronomy 28, especially, show that Jeremiah presents the 'fulfilment' of threats and curses of the Torah. They inform the book as a whole, shape its overall dynamic and form a centre of gravity for Jeremiah. What the Torah could not describe further, ${ }^{23}$ but hinted at, has been completed by the prophetic books and, most of all, by Jeremiah.

From this we may infer that one main goal of Jeremiah was to confirm the truth and validity of Moses' announcements about the consequences of disobeying God's teachings. His warnings had not been hollow, but proved themselves by becoming true in the events at the end of the monarchy, and no biblical book focuses more on this than Jeremiah.

\section{Realisation of promises}

Jeremiah is known for its 'dark' features. The emphasis on the people's guilt, the long description of the events around Jerusalem's fall in 587 BC and the years afterwards, and the overall movement towards Jeremiah 52 as a negative ending support this impression and allow one to imagine a very pessimistic view lying behind this kind of presentation.

Yet, Jeremiah also displays brighter traits. It frequently announces a 'turning around', using the phrase שוב שבות, taken from Deuteronomy 30:3. ${ }^{24}$ Jeremiah portrays God's new dealings with Israel in vivid colours and varied motifs, especially in c30-33. In these and other passages, it also alludes to former divine assurances, and it does so several times, referring to texts of the Torah likewise.

\section{Links with promises of the Book of Genesis}

God promised Noah that the changes of the seasons and the times of the day will never cease (Gn 8:22). Maybe Jeremiah picks that up, using it in oaths: 'Thus says the Lord who is giving the sun as light for the day, the orders of moon and stars as light for the night ...' (Jr 31:35), and similarly: 'Thus says the Lord: If I did not set up my covenant with day and night, the orders of heavens and earth, ...' (Jr 33:25). The allusion to the fixed alternation of day/night serves as a basis for renewed, even greater, promises in Jeremiah 31:36(-37) and 33:26 and emphasises divine reliability.

God said to Abraham that he would not destroy the evil cities if 10 just people could be found therein (Gn 18:32). Jeremiah seems to intensify this idea by God's statement that he will spare Jerusalem if one just person could be found (Jr 5:1). Ezekiel 22:30 is thematically the closest passage, with God speaking: 'And I sought among them a man who could build the wall and stand in the breach before me because of the country, in order not to destroy it; but I did not find'. Ezekiel

23. Because of its limitation, taking a standpoint in the time of Moses and outside the country.

24.Jeremiah uses this phrase eleven times, out of 25 in the OT, starting with Jeremiah 29:14, a clear indication of an emphasis on this divine action. and Jeremiah seem to emphasise God's propensity to be merciful, even beyond what happened with Sodom and Gomorrah.

The announcement to Abraham that 'nations will bless themselves in him' (Gn 22:18; 26:4) $)^{25}$ is taken up and renewed in Jeremiah 4:2. There, however, it remains unclear with regard to its reference: Who is meant by בו 'in him'? The context in Jeremiah allows for referring it either to Israel ${ }^{26}$ or to God. ${ }^{27}$ This would imply an extension of the original promise, being now applied to the people as a whole, or to the one who gave it.

God promised Jacob that he would spread in all directions (Gn 28:14). ${ }^{28} \mathrm{~A}$ list of six regions is unique to Jeremiah, which mentions areas to the West (Shefela), to the South (Negev), to the North (Benjamin) and in the area around Jerusalem (Jr $17: 26 ; 32: 44 ; 33: 13)$. This can be seen as a fulfilment of the divine promise, within the country, showing that the offspring of Jacob will cover it completely.

The command addressed to Jacob in Genesis 35:11 ' $\ldots$ and multiply' takes up former divine imperatives (Gn 1:28; 9:1). In Jeremiah 30:19 God announces, after having promised a change of fortunes for the 'tents of Jacob' in the preceding verse, that he himself will help to accomplish it: 'And I will multiply them, and they will not be few'.

\section{Links with promises of the book of Exodus}

Yahweh promises to take Israel as his people and to be their God (Ex 6:7). This is realised when God concludes the covenant with them at Mount Sinai (Ex 19-24). One manifestation of this reciprocal commitment is the 'Bundesformel'. ${ }^{29}$ Jeremiah contains the highest number of occurrences of it in its reciprocal form, ${ }^{30}$ always referring to the future. It thus emphasises the close relationship which God is continuously offering to his people.

As a precondition for concluding the covenant, God requires in Exodus 19:5 that the people will really 'listen ${ }^{31}$ to my voice'. If they are going to do so, they will become God's very special property and a holy nation. Jeremiah seems to draw on this divine offer, in various nuances. In Jeremiah 2:3, Israel is designated as 'holy'. Jeremiah 7:23 combines the phrase 'listen to my voice' with the 'Bundesformel'; this is the passage coming closest to Exodus 19. The repetition of שמע is also found ${ }^{32}$ in Jeremiah 17:24; as a result, God promises that

25.Flury-Schölch (2007) discusses at length the various blessings given to Abraham and suggests for Genesis 22:18 and 26:4 a translation as 'sich segnen werden mit and suggests for Genesis 22:18 and
deinem Samen' (p.147 and 168).

26.This is the interpretation by Abma (1999:233).

27.Thus Grüneberg (2003:217-18), and also Flury-Schölch (2007:192).

28.'He' is not to be taken literally. It includes also Jacob's descendants.

29.See Rendtorff (1995). The form ' $C$ ', which involves both parties, only occurs again in the Torah after Exodus 6:7 in Leviticus 26:12 and Deuteronomy 26:17+19; 29:12.

30.Seven times: Jeremiah 7:23; 11:4; $24: 7 ; 30: 22 ; 31: 1,33 ; 32: 38$. Ezekiel has five instances, and the only other cases are 2 Samuel 7:24 and Sach 8:8.

31. שמע is repeated twice.

32.The double repetition of שמע occurred already in Exodus 15:26; there God promised to be their healer, with the participle of $x$; $;$ this verb is found in Jeremiah $13 \times$ (out of 
kings will come, sitting on the throne of David, ... and that 'this city will sit/remain forever' (v25). Obviously, Jeremiah plays on the divine offer of Exodus 19, using elements of it on several occasions throughout the book.

In dealing with the consequences of the incident of the 'golden calf', God answers Moses' request that he should be permitted to see God's glory in Exodus 33:18 with the assurance that he will be gracious and show mercy (v19). These divine attitudes are also important for Jeremiah. The root 'mrace' occurs again in Jeremiah 31:2, alluding to a new hope and life for the people who escaped the sword. The verb רחם 'to be merciful' is used 10 times in Jeremiah. ${ }^{33}$ Although in Jeremiah 13:14 and 21:7 God refuses to grant mercy, he changes his mind and promises to be merciful and compassionate in Jeremiah 12:15; 30:18; 31:20; 33:26, and even to induce the Babylonian king to show mercy to his people in 42:12. The inner monologue of God in Jeremiah 31:20 stands out among all the usages in the Hebrew Bible, as it is the only text using רחם in the emphatic construction with absolute infinitive, to be translated as 'I will certainly have mercy ...', or 'I cannot but have mercy ...'. This reveals God's inmost feelings.

Some of God's promises in the first two books of the Bible are picked up in Jeremiah. They are repeated, renewed or reported as realised. This revives Israel's history and God's dealings with its main figures, like Noah, Abraham, Jacob and Moses, and shows that God is faithful to what he has said.

\section{Links with promises of the book of Deuteronomy}

Before starting with Deuteronomy, Leviticus 26:4 has also to be mentioned. There God announced that he would give '(heavy) rainshowers', thus fertility to the land, if Israel is obedient to his commands. Jeremiah 5:24 is the closest parallel to it, praising God for giving 'rainshowers, early and late rain in due season', thus 'over-fulfilling' his promise of Leviticus 26.

As stated above, Deuteronomy and Jeremiah are linked most intensively. This is not only true for the 'dark side' of the curses and threats, but also for those passages where Deuteronomy talks about a brighter future for the people.

In the first long parenesis, Deuteronomy 4, Moses also envisions the exile as a point of return to God:

Deuteronomy 4:29 'you (pl.) will seek Yahweh ... and you (sg.) will find, because you will ask for him with all your heart and your soul'. This announcement has its closest parallel in Jeremiah 29:13, God's message to those exiled with King Jehoiachin to Babylon: ${ }^{34}$ 'And you (pl.) will seek me and

(footnote........................ 32 continues...

67 in the OT). Other occurrences of the double שמע are Exodus 23:22; Deuteronomy $11: 13$ and Zechariah 6:15; they are always connected with a positive outcome.

33.Out of 47 occurrences within the OT; only Isaiah has more, with 12 instances.

34.Jeremiah 29 contains a 'letter' of Jeremiah to this group; the genre of this text, however, is different, and it is not clear, how far the 'letter' reaches. In any case, Jeremiah refers several times to the conveying of a divine message (Jr 29:4, 8, 10, you (pl.) will find, because/as you ask for me with all your heart'. What Moses announced, is confirmed by God.

In Deuteronomy 4:30 Moses continues: '... and you will return to Yahweh and listen to his voice'. No book of the Bible speaks more of שוב 'return' than Jeremiah, for example, in 3:14:4 (18x), and of שמע 'listen' to God's voice. ${ }^{35}$

Moses encourages Israel in Deuteronomy 4:31 by arguing: ' ... for he is a merciful God ... and does not forget the covenant with your forefathers'. Jeremiah uses the verbal root רחם 'to be merciful' 10 times (see above 3.2 with note 36 ). The request of the people: 'Remember! Don't break your covenant with us!' in Jeremiah 14:21 may be seen as a prolongation of Deuteronomy's motifs. God answers it, for example, in 31:20, 33 , although the people have repeatedly forgotten him. ${ }^{36}$

The end of Deuteronomy 5 changes its source text Exodus 20:18-21 significantly. There are some new, extended elements, for example, God's reaction on the people's request: 'Who might give it, and this would be their heart to them, to fear me, to observe all my commandments all days, in order that it may be good for them and their children forever!' (Dt 5:29). God himself takes up his wish in Jeremiah 32:39, the closest parallel to Deuteronomy 5, and promises to fulfil it even more by himself, giving his people such a heart: 'And I will give them one heart and one way, to fear me all days, for the good of them and of their children after them' ${ }^{37}$

Moses exhorts the people in Deuteronomy 5:33: '... on the whole way which Yahweh your God commanded you, you shall go, in order that you may live and it be good for you and you prolong the days on the land which you are going to inherit'. Jeremiah 7:23 is exclusively linked with this passage by '... and you shall go on the whole way which I have commanded you in order that it may be good for you' ${ }^{38}$ In this case, Moses' order that the people be obedient to God's commandments has not been followed. God reminds the people of this condition for his blessing, and in the following verses he reprimands them for not having fulfilled it (Jr 7:24-28). ${ }^{39}$

Deuteronomy 4-5 are key chapters at the beginning of this book. Moses' first parenesis and the repetition of the Decalogue, together with its extended sequel, present essentials of it, and Jeremiah picks them up and develops them further. The following chapters contain with 'streams of water' a characterisation of the country that Israel is going to inherit

$16,21,25)$. - The link between Deuteronomy $4: 29$ and Jeremiah $29: 13$ is 'exclusive' No other text uses these terms in the way the two passages combine them.

שוב.35 is used 115 times in Jeremiah (out of 1075 in the OT), and 189x (of 1194 for the OT [statistics based on Bible Works]). In both cases, Jeremiah has by far the most occurrences.

36.Jeremiah 2:32; 3:21 and more often.

37.Jeremiah 32:40 plays with motifs of the preceding verse, thus emphasising them: '... that I will do good to them; and I will give my fear into their hearts ...'.

38.The combination of these expressions is found nowhere else.

39.The concluding verse Jeremiah 7:28 contains a disastrous statement, as a kind of summarising 'definition': 'This is the people who did not listen to the voice of Yahweh, its God, and did not accept discipline'. 
(Dt 8:7; 10:7). This expression recurs again only in Jeremiah $31: 9$, there applied to the rivers along which God will lead and bring back the exiles. They may enjoy specific aspects of Israel while on the return journey.

The law corpus of Deuteronomy contains the promise of a future prophet similar to Moses in Deuteronomy 18:15-22. The genre of this text that stands at its centre, however, is different from its surroundings and thus comes 'unexpectedly'. The contrast with the context highlights the importance of this announcement, all the more as it is inserted into the dynamic of the whole book, connected with such key positions and texts such as Deuteronomy $1 ; 5 ; 13$ and $34 .{ }^{40}$

Deuteronomy 18 plays a crucial role for Jer. Right from the beginning, the call of Jeremiah picks up expressions from there in 1:7 and 1:9, the latter being a 'dramatisation' (Brandscheidt 1995:30) of it, in a unique enactment by God. Further passages alluding to or quoting Deuteronomy 18 are Jeremiah $14: 14 ; 20: 9 ; 23: 32 ; 26: 16 ; 28: 9 ; 35: 13 ; 44: 16$ - most of them being in confrontations with other prophets or conflicts involving the legitimacy of Jeremiah and his messages. ${ }^{41}$

Few texts of the Bible, and of Deuteronomy, with the exception of Chapter 28, have exercised such an enormous impact on Jeremiah. There may be two reasons for this. Firstly, it allowed Jeremiah to present 'Jeremiah' as the promised prophet like Moses, and thus to heighten his (and its) authority. Secondly, it was useful as a 'toolbox' of expressions to disqualify other prophets, their claims and their behaviour.

The latter frame of Deuteronomy sometimes takes a look into the future, too. We have seen that the curses of Deuteronomy 28 heavily influenced Jeremiah, in the phraseology as well as in the main emphasis of the entire book. The section of the blessings, albeit to a lesser extent, is taken up, too.

Deuteronomy 28:10 promises that God's 'name will be called upon you'. The people's prayer in Jeremiah 14:9 picks up that expression in the first person plural: '... and your name is called upon us'. ${ }^{42}$ In this case it is a false confidence, as they are full of guilt and sins and not willing to refrain from such behaviour, as God's answer in 14:10 makes clear.

Deuteronomy 28:11 and 30:9 indicate the direction of God's actions לטובה 'for good'. In the vision of the baskets with fig trees, God agrees, in his interpretation, with that orientation for those who have already been exiled in 597 BC (Jr 24:5).

Deuteronomy 28:13 connects a high position, using the expression 'head', with listening to (divine) commandments, keeping them and acting on them. Jeremiah 35:18 is the only

40.Sonnet (2011:41-44), and Mark I (2011) have contributed excellent interpretations of the role of Deuteronomy 18 within the book.

41.Fischer (2007:135 with note 8).

42.The terms used for God in Jeremiah 14:8-9, 'stranger', 'wanderer who deviated to stay overnight', 'confused person' and 'helpless hero', are unique in reference to him and stand, as accusations directed against him, in contrast to the people's own false behaviour. For this reason, it is no surprise that God does not listen to such prayer (Jr 14:10-12). passage in the Hebrew Bible which reports a realisation of these three verbs, to 'listen, keep, do'; there the Rechabites are said to have obeyed and executed the instructions of their forefather Jonadab.

Deuteronomy 30:3 uses for the first time the phrase שוב שבות, literally 'to revert a reversal', generally understood as 'to restore the fortunes'. Jeremiah, starting with 29:14, picks it up 11 times $^{43}$; the rest of the Hebrew Bible has 13 other occurrences all together. Jeremiah focusses on this reversal of Israel's fate more than any other book.

God's promise to circumcise Israel's heart in Deuteronomy 30:6 is based upon his order in Deuteronomy 10:16. ${ }^{44}$ Jeremiah 4:4 can be seen as a continuation and intensification of this command, as it extends it to two colons, combining elements of both source passages: 'Circumcise yourself for Yahweh, and remove the foreskins of your heart!'.

The motif of שוב, 'to return' to God, as in Deuteronomy 30:2, 8, 10 (see also Dt 4:30 above) reappears often in Jeremiah; Jeremiah 24:7 has also the complement 'with all your heart'.

God's future joy in his people and in doing good to them in Deuteronomy 30:9 has its closest parallel in Jeremiah 32:41. There God repeats the announcement given by Moses and thus revokes the curse of Deuteronomy 28:63.

In the case of Israel's love for God, Moses foretells in Deuteronomy 30:20 that the people may 'sit/dwell on the ground'. ${ }^{45}$ This phrase only occurs again in the changed oath formula of Jeremiah 23:8, in the messages of the prophets sent by God in Jeremiah 25:5, and several times in Ezek (cf. Fischer 2005a:737). It signifies that God remains faithful to his promise.

In Deuteronomy 31:6, Moses finishes his speech to Israel by saying that God will not 'forsake' them. The people take up this motif in their prayer in Jeremiah 14:9, relying on Moses' announcement, albeit not really willing to change their sinful behaviour. $^{46}$

The Song of Moses, in its final part, also envisages a positive outcome for God's relationship with his people in the future. From Deuteronomy 32:36 onwards it announces that he will 'have mercy', including 'healing' (v39), and using a 'sword' for his judgement (v41). The first two motifs have already been treated (cf. above 3.2 and notes 34-35); the latter motif occurs also in Jeremiah 25:31 and 47:6. ${ }^{47}$

43.cf. above note 27. Jeremiah uses the expression often in similar contexts as in Deuteronomy 30; see, for example, the terms 'dispersed', 'have mercy' in Jeremiah $30: 18 ; 33: 26, \ldots$

44.Deuteronomy 10 has in addition the 'foreskin' (of the heart); for the enormous significance of this motif in Deuteronomy and for the whole Torah, see Ehrenreich (2010:156-188).

45.Deuteronomy 30:20 employs אדמה 'ground', not the usual ארץ 'land, country'.

46.See above the interpretation given for Deuteronomy 28:10.

47.Maybe also the root נקם 'just retribution' in relation to foes, as in Deuteronomy 32:35, has inspired Jeremiah, for example, for the judgements upon Egypt and Babylon in 46:10; 50:15, 28; 51:6 
Moses' blessing of Benjamin in Deuteronomy 33:12 foresees that 'he will dwell in safety with/upon him'.48 The passages coming closest to this expression are Psalms 16:9 - they are, however, referring to an individual - and Jeremiah 23:6 // 33:16, applied to Israel and Jerusalem, respectively.

The common perception of Jeremiah conceives it as a rather dark, sombre book. It is largely dominated by disaster, destruction, descriptions of calamities, despair. Therein Jeremiah brings the realisation of earlier curses, especially of Deuteronomy 28 (see above 2). This general impression, however, is just one side. To counterbalance it, I have addressed the issue of the fulfilment of promises of the Torah in Jeremiah, and given them more space and attention here. We have already seen that Jeremiah has also taken up promises.

The connections with the Books of Genesis and Exodus are not compelling, as they are not very specific. It is different with Deuteronomy, where chapters 4-5; 18 and 30, in particular, offer several and close links with Jeremiah. Jeremiah 1 can be seen as fulfilment of the promises of God and Moses in Deuteronomy 18. The other announcements, mostly refer to the time/experience of the exile, ${ }^{49}$ are picked up in a major way in Jeremiah 24; 29 and 32 and remain open even there, thus forming a continuing program. Jeremiah 'revitalises' the old promises, connects them with foreign domination and underlines still more God's engagement and the conditions ${ }^{50}$ for a good and lasting relationship with him.

\section{The relationship between the Book of Isaiah and the Book of Jeremiah}

This final chapter brings together two aspects. As the title of the conference specified Isaiah and Jeremiah as figures and books to concentrate upon, it seemed appropriate to deal with the relationship between these two great prophets. Secondly, Isaiah and Jeremiah display a very different profile with regard to threats and promises. Isaiah is perceived as being full of 'light and hope'; Jeremiah appears to be the opposite. Therefore, it is interesting to compare them in this respect. Before doing so, we have to reflect briefly on the method of the approach to their relationship.

Normally, most exegetes assume that 'First Isaiah lies before Jeremiah, ${ }^{51}$ and that this sequence is turned around with 'Second Isaiah', whose texts are regarded as being later than those of the prophet Jeremiah. ${ }^{52}$ This presupposes:

a. that texts of Proto-Isaiah can be connected with the prophet Isaiah in the 8th century BC, thus being prior to the prophet Jeremiah towards the end of the 7th century BC

b. that texts of 'Second Isaiah' come from the time of the exile and later

48. There is a similar wording towards the end in Deuteronomy $33: 28$.

49.This is especially true for the relevant passages in Deuteronomy 4 and 30.

50.To 'listen to God's voice' is prominent among them. Jeremiah strongly emphasises it. 51.For example, Wendel (1995). She analyses how proto-Isaian texts have influenced Jer.

52.Such a position is put forward by Sommer (1996), Glaßner (1991), and many others. c. in addition, that the Book of Jeremiah can be attributed to the prophet, living, at least partly, around $600 \mathrm{BC}$.

These three presuppositions, however, pose a problem. The preconceived datings of the respective (parts of) books and their attribution to prophets as authors has come into question (see also above 1.3). Furthermore, the recognition of late(r) redactional reworking of the prophetic books leaves open the option that the direction of dependence might be the other way round. To arrive at firm conclusions, we have to investigate purely on the literary level, trying to discover possible connections and, eventually, to detect who borrowed from whom.

\section{Common ground}

Isaiah and Jeremiah share many features; I will just mention a few of them here:

a. Both prophetic books pick up longer texts from 2 Kings. Isaiah 36-39 has its roots in 2 Kings 18-20 (Berges 1998:266277), Jeremiah 52 uses 2 Kings 24:18-25:30 as a source.

b. Isaiah and Jeremiah also draw on central passages of the prophet Micah: Isaiah 2:2-4 is largely parallel to Micah 4:1-3, whereas the two preceding verses Micah 3:11-12 seem to have informed Jeremiah 14:9; 5:12, and 26:18.

c. Both books present a suffering figure in an elaborate manner. In Isaiah it is the 'servant of Yahweh', in Jeremiah the prophet himself.

d. Both share many expressions and motifs. The scroll of consolation (Jr 30-31) alone is very close to the following Isaian texts: Isaiah 10:27 // Jeremiah 30:8; Isaiah 16:11 // Jeremiah 31:20; Isaiah 51:15 // Jeremiah 31:35; Isaiah 58:11 / / Jeremiah 31:12.53

In conclusion: The multitude of connections points to a literary kind of relationship. Isaiah and Jeremiah coincide in many ideas, concepts and words - they are partners ${ }^{54}$ and 'brothers'.

\section{Differences}

The common features cannot hide the fact that these two prophetic books are miles apart. Some of the indications of their enormous distance from each other are:

a. In picking up 2 Kings, Isaiah brings Zion's salvation into the middle of the book, Jeremiah its destruction at the end.

b. In picking up Micah, Isaiah chooses a passage highlighting Jerusalem's positive role, whereas Jeremiah selects the immediately preceding verse, announcing its devastation.

53.For more correspondences, see Fischer (1993:209).

54.This expression picks up the title of an article of mine: 'Partner oder Gegner', originally published in the FS for Ina Willi-Plein (2007), new in Fischer (2011: 188-199). 
c. The prophet Jeremiah 'surpasses' the servant of Yahweh. If one compares Isaiah 49:1-6 and 53:6-8 with Jeremiah 1:5; $11: 19$ and $15: 11.15,{ }^{55}$ the portrayal of Jeremiah seems to extend and even intensify the suffering of God's servant in Isa.

d. Jeremiah questions the positive outlook for Zion, as can be seen in the reversals of Isaiah 60:6, 18 in Jeremiah 6:20, 7. In a similar way the image of Lady Zion receiving healing in Isaiah 54 is contrasted by Jeremiah $4 .{ }^{56}$

e. The repeated expression: 'Peace! Peace!' occurs in Isaiah 26:3 and 57:19, otherwise only in 1 Chron 12:19, and is countered in Jeremiah 6:14 // 8:11 as announcement of false prophets.

Taking these and other observations together, there appears to be a substantial distance between these two prophetic books. Their fundamental orientation and dynamic is very different, and also the elaboration of similar motifs points to diverse, even contrasting, attitudes and directions. Isaiah and Jeremiah are 'unequal brothers'.

\section{Interpretation}

In freeing myself from the 'classical' sequence 'First Isaiah Jer $\rightarrow$ Second Isaiah', Berlejung's observation that Jeremiah 10 presupposes the critique of idolatry in Isaiah 44 has proved helpful. ${ }^{57}$ It is possible that texts of the so-called 'DeuteroIsaiah" ${ }^{58}$ and even of "Trito-Isaiah" ${ }^{\prime 59}$ may be the source for Jeremiah. This is especially true for the connections with the 'servant songs' and the salvation vocabulary mentioned in 4.1.

Judging the differences (4.2) on a literary level, we can perceive all kinds of deliberate reworking on the part of Jeremiah. It seems as if Jeremiah is reacting to Isaiah in various ways:

- questioning concepts of hope and salvation (Jr 4 and 6)

- open dissent indicated by the accusation ' (try) to heal על־נקלה [too easily]', in Jeremiah 6:14, repeated in 8:11, as reproach against (false) prophets

- insisting on the yet unredeemed situation (Jr 52) and the preconditions for recovery (Jr 4:14)

- going still further than Isaiah by intensifying its expressions and concepts (cf. Jr 1; 11; 15 ...) and combining them with motifs from many other biblical books (see above 1.3).

As a result, Isaiah and Jeremiah may be seen as two complementary perspectives. Although Isaiah draws a shining 55.See my articles (2012b:284-287), and (2013:77-89).

56.Contra Glaßner (1991:233-241), who assumes Isaiah 54 having been influenced by Jeremiah 4.

57.Berlejung (1998: 391). She confirmed my impression at the investigation of Jeremiah 30-31 that this 'Trostbüchlein' takes up phrases from Isaiah 40-66.

58.For caution with respect to this expression and taking Isaiah 55 as an end of it, see Paganini (2002:especially 199).

59.Thus, recently Leene (2014:312). He succeeds in demonstrating the dependence of Jeremiah with respect to the motif 'new' on the concepts and texts of the entir Book of Isaiah as well as on Ezekiel. picture of Zion as God's bride, Jeremiah conveys a rather sober image of Jerusalem as being stricken in sin. In my eyes, Jeremiah thus reacts to the too 'optimistic' outlook of the Book of Isaiah and tries to direct attention to a more realistic perception of the situation and the necessity of more 'human collaboration' for the restoration of Israel. God's promises are valid, and he is faithful, but the people, on their part, have to make more of a contribution.

The focus on Torah promises and their realisation in the Book of Jeremiah and its comparison with Isaiah revealed interesting insights. Jeremiah is not so exclusively concentrated on the 'negative side', on threats, disaster and calamity, as one might deduce from an overall impression or first reading. Jeremiah also reflects on ancient divine promises, shows their ongoing validity and with it God's faithfulness, thus fostering a more solid hope and genuine consolation. ${ }^{60}$ These latter aspects seem prominent in comparison to Jer's 'partner book', Isa, which puts more emphasis on the 'bright side' and whose long, consoling and encouraging texts might induce the reader to downplay the necessity of a change of behaviour in society and in individuals. Isaiah and Jeremiah, both agree on God's final plans for the people's welfare and on his being faithful to his promises.

\section{Acknowledgements}

The author is grateful to Jurie le Roux for the invitation to this congress, at such a wonderful location as Bass Lake Country Lodge is, and the extraordinary hospitality of all the colleagues in South Africa. It remains an unforgettable experience. The author also thanks Mrs Felicity Stephens for correcting the English of this article.

\section{Competing interests}

The author declares that they have no financial or personal relationships which may have inappropriately influenced them in writing this article.

\section{Author's contributions}

G.F. SJ is the sole contributor to this research article.

\section{Ethical considerations}

This article followed all ethical standards for research without direct contact with human or animal subjects.

\section{Funding information}

Funding for the article processing fees was provided by the University of Pretoria.

$60 . H o p e$ and consolation in Jeremiah, are based on accepting God's judgement (Jr 24 $29 ; 30-31 \ldots)$, as a foundation for new life. Isaiah $40: 1-2$ establishes the same link; $29 ; 30-31 \ldots)$, as a foundation for new life. Isaiah $40: 1-2$ establishes the same link;
overall, however, Isaiah tends to develop more intensively the theme of divine grace. 


\section{Data availability statement}

Data sharing is not applicable to this article as no new data were created or analysed in this study.

\section{Disclaimer}

The views and opinions expressed in this article are those of the author and do not necessarily reflect the official policy or position of any affiliated agency of the author.

\section{References}

Abma, R., 1999, Bonds of love: Methodic studies of prophetic texts with marriage imagery, SSN 40, Van Gorcum, Assen.

Berges, U., 1998, Das Buch Jesaja. Komposition und Endgestalt, HBS 16, Herder, Freiburg.

Berlejung, A., 1998, Die Theologie der Bilder, ОВО162, Universitätsverlag, Fribourg.

Boda, M.J., 2001, 'From complaint to contrition: Peering through the Liturgical Window of Jer 14,1-15,4', ZAW 113(2), 186-197. https://doi.org/10.1515/ zatw.113.2.186

Brandscheidt, R., 1995, “"Bestellt über Völker und Königreiche” (Jer 1,10). Form und tradition in Jeremia 1 ', TThZ 104(1), 12-37.

Braulik, G., 1997, 'Das Deuteronomium und die Gedächtniskultur Israels. Redaktionsgeschichtliche Beobachtungen zur Verwendung von ${ }^{\prime}{ }^{\prime}$, in G. Braulik (ed.), Studien zum Buch Deuteronomium, SBAB 24, pp. 119-146, Katholisches (ed.), Studien zum Buct
Bibelwerk, Stuttgart.

Carroll, R.P., 1986, Jeremiah, OTL, Westminster Press, London.

Ehrenreich, E., 2010, Wähle das Leben! Deuteronomium 30 als hermeneutischer Schlüssel zur Tora, BZAR 14, Harrassowitz, Wiesbaden.

Fischer, G., 1993, Das Trostbüchlein. Text, Komposition und Theologie von Jer 30-31, SBB 26, Katholisches Bibelwerk, Stuttgart.

Fischer, G., 2005a, Jeremia 1-25, HThKAT, Herder, Freiburg.

Fischer, G., 2005b, Jeremia 26-52, HThKAT, Herder, Freiburg.

Fischer, G., 2007, Jeremia. Der Stand der theologischen Diskussion, Wissenschaftliche Buchgesellschaft, Darmstadt.

Fischer, G., 2011, Der Prophet wie Mose. Studien zum Jeremiabuch, BZAR 15, Harrassowitz, Wiesbaden.

Fischer, G., 2012a, 'Fulfilment and reversal: The curses of Deuteronomy 28 as a foil for the book of Jeremiah', Semitica et Classica 5, 43-49. https://doi.org/10.1484/J. SEC.1.103046
Fischer, G., 2012b, 'Riddles of reference: "l" and "We" in the books of Isaiah and Jeremiah: The relation of the suffering characters', Old Testament Essays 25(2), 277-291.

Fischer, G., 2013, 'Jeremiah, God's suffering servant', in E.M. Obara \& G.P.D. Succu (eds.), Uomini e profeti, pp. 75-101, FS H. Simian-Yofre SJ, Gregorian \& Biblical Press, Rom.

Fischer, G., 2015, Jeremia. Prophet über Völker und Königreiche, Biblische Gestalten 29, Evangelische Verlagsanstalt, Leipzig.

Flury-Schölch, A., 2007, Abrahams Segen und die Völker. Synchrone und diachrone Untersuchungen zu Gen 12,1-3 unter besonderer Berücksichtigung der intertextuellen Beziehungen zu Gen 18; 22; 26; 28; Sir 44; Jer 4 und Ps 72, FzB 115, Echter, Würzburg.

Glaßner, G., 1991, Vision eines auf Verheißung gegründeten Jerusalem. Textanalytische Studien zu Jesaja 54, ÖBS 11, Österreichisches Katholisches Bibelwerk, Klosterneuburg.

Grüneberg, K.N., 2003, Abraham, blessing and the nations: A philological and exegetical study of genesis 12:3 in its narrative context, BZAW 332, de Gruyter, Berlin.

Holladay, W.L., 1986, Jeremiah 1. Chapters 1-25, Hermeneia, Fortress, Philadelphia, PA. Holladay, W.L., 1989, Jeremiah 2. Chapters 26-52, Hermeneia, Fortress, Philadelphia, PA. Köckert, M., 2000, 'Zum literargeschichtlichen Ort des Prophetengesetzes Dtn 18 zwischen dem Jeremiabuch und Dtn 13', in R.G. Kratz \& H. Spieckermann (eds.), Liebe und Gebot, pp. 80-100, FRLANT 190, FS L. Perlitt, Vandenhoeck \& Ruprecht, Göttingen.

Leene, H., 2014, Newness in Old Testament prophecy. An intertextual study, OTS 64, Brill, Leiden.

Lundbom, J.R., 1999, Jeremiah 1-20, AB 21A, Doubleday, New York.

Lundbom, J.R., 2004a, Jeremiah 21-36, AB 21B, Doubleday, New York.

Lundbom, J.R., 2004b, Jeremiah 37-52, AB 21C, Doubleday, New York.

Markl, D., 2011, 'Moses Prophetenrolle in Dtn 5; 18; 34. Strukturelle Wendepunkte von rechtshermeneutischem Gewicht', in G. Fischer, D. Markl \& S. Paganini (eds.), Deuteronomium - Tora für eine neue Generation, pp. 51-68, BZAR 17 Harrassowitz, Wiesbaden

Paganini, S., 2002, Der Weg zur Frau Zion, Ziel unserer Hoffnung. Aufbau, Kontext, Sprache, Kommunikationsstruktur und theologische Motive in Jes 55,1-13, SBB 49, Katholisches Bibelwerk, Stuttgart.

Rendtorff, R., 1995, Die 'Bundesformel'. Eine exegetisch-theologische Untersuchung, SBS 160, Katholisches Bibelwerk, Stuttgart.

Sommer, B.D., 1996, 'Allusions and illusions. The unity of the book of Isaiah', in M.A. Sweeney, R.F. Melugin (eds.), New visions of Isaiah, pp. 156-186, JSOTS 214 Sheffield Academic Press, Sheffield.

Sonnet, J.-P., 2011, "'Redefining the plot of deuteronomy" - From end to beginning. The import of Deut 34:9', in G. Fischer, D. Markl \& S. Paganini (eds.), Deuteronomium - Tora für eine neue generation, pp. 37-50, BZAR 17, Harrassowitz, Wiesbaden.

Wendel, U., 1995, Jesaja und Jeremia. Worte, Motive und Einsichten Jesajas in der Verkündigung Jeremias, BThSt 25, Neukirchener Verlag, Neukirchen. 